Article

\title{
Acoustic Simulation of Julius Caesar's Battlefield Speeches
}

\section{Braxton Boren (iD}

Audio Technology Program, Department of Performing Arts, College of Arts \& Sciences, American University, Washington, DC 20016, USA; boren@american.edu; Tel.: +1-202-885-1482

Received: 14 September 2018; Accepted: 10 October 2018; Published: 14 October 2018

\begin{abstract}
History contains many accounts of speeches given by civic and military leaders before large crowds prior to the invention of electronic amplification. Historians have debated the historical accuracy of these accounts, often making some reference to acoustics, either supporting or refuting the accounts, but without any numerical justification. The field of digital humanities, and more specifically archaeoacoustics, seeks to use computational techniques to provide empirical data to improve historical analysis. Julius Caesar recalled giving speeches to 14,000 men after the battle of Dyrrachium and another to 22,000 men before the battle of Pharsalus during the Roman Civil War. Caesar's background and education are discussed, including his training in rhetoric and oratory, which would have affected his articulation and effective sound pressure level while addressing his troops. Based on subjective reports about Caesar's oratorical abilities, his effective Sound Pressure Level (SPL) is assumed to be $80 \mathrm{dBA}$, about $6 \mathrm{~dB}$ above the average loud speaking voice but lower than that of the loudest trained actors and singers. Simulations show that for reasonable background noise conditions Caesar could have been heard intelligibly by 14,000 soldiers in a quiet, controlled environment as in the speech at Dyrrachium. In contrast, even granting generous acoustic and geometric conditions, Caesar could not have been heard by more than about 700 soldiers while his army was on the march before the battle of Pharsalus.
\end{abstract}

Keywords: acoustics; history; Julius Caesar; digital humanities; archaeoacoustics; acoustic simulation; historical speeches; general's harangue; military history

\section{Introduction}

Throughout most of human history, electronic amplification of the spoken word was unavailable; therefore, all human gatherings were effectively limited in size by the acoustic range over which the person speaking could be heard intelligibly. Many of the largest reported crowds in history are records of generals delivering a speech or "harangue" to an army [1], since the army's numbers were counted and thus represent a relatively rare instance of a counted crowd in ancient history (although there is certainly a large range of error in all-ancient and modern-crowd-counting methods [2,3]). These accounts were generally accepted by modern historians (e.g., [4,5]) until a landmark paper by Mogens Herman Hansen in 1993, which cast doubt upon the entire historicity of a general's speech to the army [6]. Hansen made many historical and textual arguments that need not be reproduced here in detail, but among these, he made acoustical claims, such as the area over which an ancient phalanx stretched, or noise from rattling hoplite armor, leading him to conclude that

Under such circumstances it must have been impossible for a general, even if he had had the voice of a Stentor, to deliver a speech that could be heard by all the soldiers simultaneously [6].

Though propagation distance and background noise are certainly valid acoustical criteria to examine, the sentence above contains all the acoustical analysis the author thought necessary to 
include in his paradigm-shattering thesis. Of course, the problem with vague allusions to scientific truth to prove a point is that the other side can allude to science just as vaguely, which is indeed what happened in this case: a year later, the historian W. Kendrick Pritchett replied with a 100-page rejoinder defending the authenticity of the general's harangue, listing in detail different accounts of speeches to large crowds from ancient Greece and Rome, and also including more recent accounts, from Henry $\mathrm{V}$ at Agincourt to George Washington [7]. Pritchett mentioned these military examples as well as another from the preacher John Wesley, arguing that it is acoustically possible for a single speaker to reach such a large assembly.

This tendency to enlist science as an ally without careful numerical consideration often leads to an abuse or neglect of the specific issues in question. For example, Hansen's example of rattling hoplite armor, to which he returns several times in his essay, is based on a single reference to Alexander the Great in the midst of a great battle, rather than hoplites standing at attention before battle ([8], 4.13.37). In turn, Pritchett's reference to John Wesley uncritically accepted Wesley's estimate using an assumed crowd density of five people per square yard [9], while modern crowd estimation methods show that in large gatherings the highest densities achieved are less than half that value [10]. In such cases, quantitative references are somewhat superfluous; they are enlisted not to elucidate the past, but because the historians have already made up their minds and want to give their argument a veneer of scientific credibility (as some have asserted, "There are no statistics in ancient sources, just rhetorical flourishes made with numbers" [11]).

Humanities disciplines (including History, although it sometimes presents itself as Social Science instead) primarily interpret empirical facts which in themselves are not contested. The arguments employed in this process of interpretation are not (and in a sense cannot be) quantitative. Different historians come to different conclusions on the basis of the same collection of facts. The field which primarily seeks to collect empirical facts to be interpreted is not history but archaeology. In the past, archaeology focused on the excavation of physical artifacts, but recently has embraced computational methods to expand the range of acceptable empirical data [12]. This is a specific application of the movement generally known as the digital humanities, which seeks to use computational methods to shed light on uncontroversial but not immediately obvious facts, which may themselves be the basis for further humanistic interpretation and inquiry. The sub-field variously known as acoustic archaeology or archaeoacoustics uses computational acoustic simulation to uncover facts about the nature of sound in history, which is necessary to address the issue raised by Hansen and Pritchett's disagreement.

Both papers make reference to Julius Caesar's speeches to his army, both during the Gallic Wars and the Roman Civil War. The speeches during the Gallic Wars are smaller and less contested, but during the Civil War Caesar records giving two major speeches to large gatherings of soldiers, one following his army's defeat at the battle of Dyrrachium, and one immediately before the battle of Pharsalus, both in 48 BC [13]. This paper examines the historicity of these accounts through archaeoacoustic simulations of the speeches as Caesar describes them. Using this framework, it can be shown that, even without every historical detail preserved exactly, the plausibility or implausibility of certain historical speeches may be known with a high degree of certainty once we examine the acoustical evidence.

\section{Background}

After the controversy between Hansen and Pritchett, other historians writing on these speeches referenced the debate, but generally avoided making strong claims about whether these speeches actually occurred [14-16]. Again, this reticence may be a combination of not feeling comfortable with quantitative acoustics, as well as a general feeling that sound as a transient phenomenon is more or less lost to history once it is silenced. As it happens, there is a long tradition of working backwards through known physical laws to study sounds of the past, motivated by this same question: How many listeners can hear a single human voice? 


\subsection{Benjamin Franklin's Experiment}

In 1739, the Methodist revivalist preacher (and friend of John Wesley) George Whitefield drew large outdoor crowds in London that were estimated as high as 80,000 people [17]. Across the Atlantic, Benjamin Franklin, who was at that time the publisher of The Pennsylvania Gazette in Philadelphia, had stopped printing the estimates of Whitefield's crowds because he thought they were exaggerated. Franklin described in his autobiography how he carried out an experiment to measure Whitefield's intelligible distance when the preacher came to Philadelphia. Using a semicircular approximation for the crowd shape, Franklin calculated that

... [Whitefield] might well be heard by more than Thirty Thousand. This reconciled me to the newspaper accounts of his having preached to twenty five thousand people in the fields and to the ancient histories of generals haranguing whole armies of which I had sometimes doubted [18].

While Franklin used Whitefield's example as a conduit to explore the vocal ranges of ancient generals, the data from his experiment also provide information about Whitefield's vocal level, as the preacher was known for having one of the loudest voices of his generation [19]. Data from Franklin's experiment have been used to infer noise characteristics based on known noise sources and site geometry [20], study the maximum sound pressure [21] and directivity patterns for trained vocalists [22], and to simulate Whitefield's own maximum SPL and crowd size based on Franklin's data [23]. This work estimated that Whitefield's time-averaged on-axis $\mathrm{L}_{\mathrm{eq}}$ could be as great as $90 \mathrm{~dB}_{\mathrm{A}}$, about $16 \mathrm{~dB}$ greater than the ANSI standard [24] for "loud speech" (about $74 \mathrm{~dB}$ when the ANSI spectrum is A-weighted [25]), and still significantly higher than that for "shouted speech" (about $82 \mathrm{~dB}_{\mathrm{A}}$ ). The corresponding ISO standard uses more discrete vocal levels, but similarly has its highest value of "Very Loud" speech as $78 \mathrm{~dB}$ after A-weighting is applied [25,26].

High vocal levels allow for animal communication at very long distances, producing an evolutionary sexual selection effect [27], which may vestigially influence human vocal capacity today. The computer simulations predicted that Whitefield could be heard intelligibly by a crowd of over 20,000 people without assuming overly optimistic acoustic conditions, although the reported crowd of 80,000 is acoustically implausible even under very favorable conditions [23].

This example shows that there exist regions of plausibility between being naively accepting or close-mindedly skeptical of all historical accounts of speeches to large crowds. Using what is already known about the human voice, sound propagation, and speech intelligibility, we can give a good approximation of how many people could hear a speaker on a specific occasion. While we cannot affix a precise crowd size to every historical account, we can shed a good deal of light on the historical account, which may inform the way we interpret the original text.

Even in situations where we do not have data as convenient as that which Franklin recorded, we can investigate a range of possible acoustic conditions (e.g., background noise). We can simulate the extreme "optimistic" and "pessimistic" ends of this range of conditions to better understand the historical situation. If, even under pessimistic conditions, the intelligibility (measured by the speech transmission index (STI)) is still acceptable throughout the crowd, we may consider the historical account plausible even if we cannot know the precise noise condition without the benefit of a time machine. Conversely, if under optimistic conditions the intelligibility is still too low throughout the simulated crowd, we may consider the account acoustically implausible. To apply this method to Caesar's speeches, we need to first consider his voice, the sites of his speeches, and the background noise present.

\subsection{Caesar the Orator}

Vocal training is an important factor to the maximum pressure achievable by a speaker [28], and Caesar received extensive training from childhood on. Though most famous for his achievements as a general and later as dictator, Julius Caesar was born in 100 BC into a high family in the Roman 
Republic and was trained from childhood to perform the public ceremonies required of the family's inherited priesthood, and Caesar would later assume the title of pontifex maximus, the high priest of all Rome (the Latin title was later also given to the Bishop of Rome, i.e., the Pope) [29]. In 70 BC, Caesar traveled to the island of Rhodes to study oratory with the noted rhetoritician Apollonius Molon, who also trained Cicero in oratorical delivery [30]. In addition to his smaller speeches to his centurions or smaller military gatherings, Caesar also gave a noted speech in the Roman Senate advocating mercy for the Cataline conspirators in 63 BC [31].

In addition to the many examples of Caesar's experience with oratory, no less an orator than Cicero himself (who also wrote an entire text on the subject [32]) testified to the quality of Caesar's delivery. In a letter to Cornelius Nepos, Cicero wrote

Do you know any man who can speak better than Caesar, even if he has concentrated on the art of oratory to the exclusion of all else? [33]

Despite his natural talent for oratory, Caesar chose to pursue the military instead of oratory as his chief vocation, and thus might not be expected to have perfected his delivery to the extent reported for speakers such as Demosthenes, who is reported to have undertaken specific exercises to perfect his elocution, lung control, and overall level [34]. In addition to vocal training, youth is also correlated with maximum vocal output, the level decreasing with increasing age [35]. In this regard, Caesar was no longer so young (52) at the time of the civil war in $48 \mathrm{BC}$, and thus simulations of his battle speeches cannot assume that he was near the highest vocal levels possible $\left(90 \mathrm{~dB}_{\mathrm{A}}\right)$, as in the case of Whitefield, who was only 24 at the time of Franklin's experiment. Because of this, a more moderate averaged SPL range of $74-80 \mathrm{~dB}_{\mathrm{A}}$ is assumed for Caesar in the computer models.

\section{Simulation Method and Results}

\subsection{Dyrrachium}

\subsubsection{Environmental Factors}

In $49 \mathrm{BC}$, fearing prosecution if he lost his military position, Caesar "crossed the Rubicon" into Italy without resigning his military command, initiating the Civil War between his followers, known as the Populares, and the Optimates, who followed Pompey the Great. Caesar followed Pompey's army into Greece, where the two battles both occurred. Pompey's forces managed to break through Caesar's lines at the city of Dyrrachium, leading to a rare decisive defeat for Caesar's army. After the battle he recounted

Caesar was now forced to abandon his previous plans and believed that he needed to change his entire strategy for this war. Accordingly, he simultaneously withdrew his troops from all their fortified positions, thus ending the siege. He gathered his entire army in one place and addressed the troops in assembly, urging them not to be discouraged by what had happened: they should neither be frightened by their present experience nor consider this single setback-which, at any rate, was relatively minor-as equivalent to their many successful battles [13].

After the speech, Caesar reports that his army successfully withdrew from Pompey's larger force, setting up the later conflict at Pharsalus. The exact location of the speech is not recorded by Caesar or later historians, so it is unknown if there were any distinguishing surfaces or geometric properties which may have aided or impaired speech intelligibility. However, he had retreated from his former fortifications, so it is reasonable to assume it took place on the plain to the east, along the line of Caesar's retreat, a relatively flat area. According to Caesar's own account, he had about 15,000 troops at Dyrrachium, and his losses from the battle were about 1000, suggesting that his entire army at the time of his speech consisted of about 14,000 [13]. 
Hansen did not address Caesar's speech at Dyrrachium, as assemblies of armies not in formation do not meet his criteria for a "battlefield speech". He even noted that, since on such an occasion the troops could be drawn up closer together, such assemblies are at least plausible [6]. However, it is certainly a historical account of a single speaker addressing a crowd of 14,000 , which is a difficult task for most untrained vocalists and thus merits further investigation.

Despite Hansen's repeated concerns about rattling armor, as mentioned before, the only text he cites refers to noise during battle, not before or after. In fact, Caesar's legions at Dyrrachium consisted of battle-hardened soldiers who were intensely loyal to him and adept at moving or being still in a coordinated fashion (in fact, this second quality would more or less win the war for Caesar at Pharsalus). Caesar mentioned that "much self-reproach came over the entire army because of the disaster" which suggests a sombre tone over the whole assembly as their general spoke to them [13]. Assuming that the soldiers could be still and attentive during such a speech, a moderate background noise level of $45 \mathrm{~dB}_{\mathrm{A}}$ seems reasonable based on the subjective descriptors of the occasion.

\subsubsection{Simulation}

The speech at Dyrrachium was modeled in CATT-Acoustic v9.1b [36,37]. Exact environmental data are not available, but the speech occurred in July and the weather was described as quite hot [13], so the model was assigned an air temperature of $27^{\circ} \mathrm{C}$, with $50 \%$ humidity, near the mid-summer averages for central Greece today, though to the author's knowledge no more exact temperature data are available for this period. Although geometric acoustic simulations (e.g., CATT) do not fully account for some wave effects [38,39], in this case, the model was needed only for propagation attenuation and STI calculation, so the geometrical model is sufficient for the level of historical precision that is known about the speech. CATT's diffraction prediction algorithm was enabled, allowing the simulation to account for the acoustic ground effect [40].

The model included a large map of a flat crowd, larger than that reported ( $200 \mathrm{~m}$ by $200 \mathrm{~m})$, with assumed density of 2.7 people per $\mathrm{m}^{2}$, corresponding to "strong" crowd conditions but not the extreme of "mosh-pit" conditions [10]. The modeled crowd's absorption coefficients are given in Table 1 using values measured in [41], and corresponding scattering coefficients were predicted based on an assumed average roughness depth of $0.1 \mathrm{~m}$ in CATT. Here and at Pharsalus, the measured Sabine absorption values were greater than 1 for the highest frequencies, but this is an artifact of the Sabine calculation. Since geometric acoustical simulations cannot accept values greater than 1 , all such values were truncated to 0.99, as indicated in [37]. Above this, a source representing Julius Caesar was situated $1 \mathrm{~m}$ above the crowd, with listeners on all sides of him, assuming that his army would crowd around all sides to be able to hear him better.

Caesar's voice was simulated using a standard male vocal directivity pattern in CATT, since more specific information about Caesar's head shape or directivity pattern probably cannot be known. Caesar's voice was modeled with a steady-state $\mathrm{L}_{\mathrm{eq}}$ ranging from $74 \mathrm{~dB}_{\mathrm{A}}$ (standard "loud" speech) to $80 \mathrm{~dB}_{\mathrm{A}}$ (closer to "shouted" speech) at $1 \mathrm{~m}$ and a standard male vocal spectrum (which CATT calculates directly from the ANSI-1997 standard spectrum based on simulated level [37]). Background noise was modeled as $45 \mathrm{~dB}_{\mathrm{A}}$.

Table 1. Absorption coefficients by octave band center frequency $(\mathrm{Hz})$ for standing soldiers in Dyrrachium model (2.7 persons per $\left.\mathrm{m}^{2},[41]\right)$.

\begin{tabular}{ccccccc}
\hline Surface & $\mathbf{1 2 5}$ & $\mathbf{2 5 0}$ & $\mathbf{5 0 0}$ & $\mathbf{1 0 0 0}$ & $\mathbf{2 0 0 0}$ & $\mathbf{4 0 0 0}$ \\
\hline Audience area (dense) & 0.24 & 0.47 & 0.94 & 0.99 & 0.99 & 0.99 \\
\hline
\end{tabular}

After the simulations, CATT exported grid maps of the crowd, representing the Speech Transmission Index (STI) in each $2 \mathrm{~m} \times 2 \mathrm{~m}$ square. From these, the minimum intelligible area (MIA), defined as the area over which STI $\geq 0.3$ was calculated for each grid with a custom Matlab script. 0.3 
was first used as a threshold of intelligibility in [23] because the phoneme-group score for various word groups drops precipitously below this value [42], leading STI measures below this to be characterized as "bad" intelligibility. Based on the source vocal level, the MIA is predicted to range from 2104 to $8096 \mathrm{~m}^{2}$, as shown in Figure 1 (Caesar's position is shown by a yellow dot). Final predicted intelligible crowd sizes are 2.7 multiplied by the MIA, assuming a density of 2.7 persons per $\mathrm{m}^{2}$, as shown in Table 2.

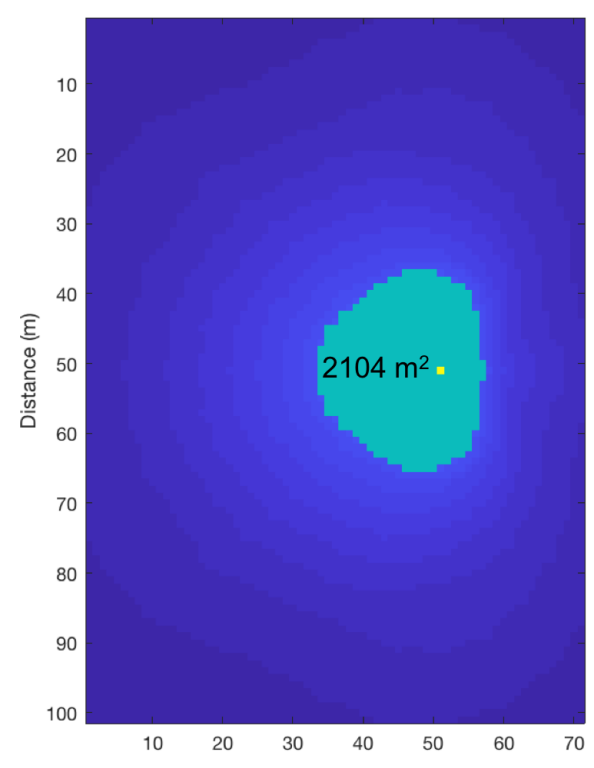

(a)

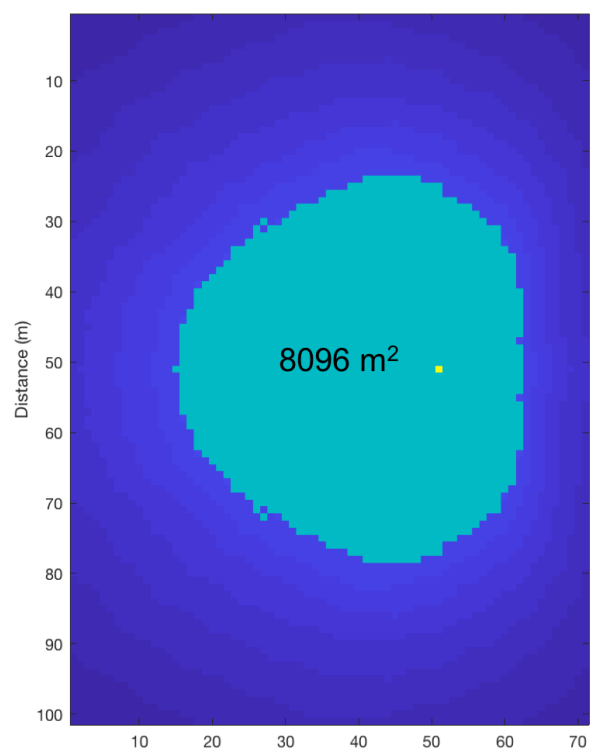

(b)

Figure 1. Minimally Intelligible Area (MIA) at Dyrrachium Based on Source Vocal Level: (a) $74 \mathrm{~dB}_{\mathrm{A}}$ source; and (b) $80 \mathrm{~dB}_{\mathrm{A}}$ source.

Table 2. Modeled crowd size, area, and density by vocal source level.

\begin{tabular}{|c|c|c|c|c|}
\hline Vocal SPL ( $\left.\mathrm{dB}_{\mathrm{A}}\right)$ & Background Noise Level $\left(\mathrm{dB}_{\mathrm{A}}\right)$ & MIA $\left(\mathrm{m}^{2}\right)$ & Density (Persons/m²) & Crowd Size \\
\hline 74 & 45 & 2104 & 2.7 & 5,681 \\
\hline 80 & 45 & 8096 & 2.7 & 21,859 \\
\hline
\end{tabular}

\subsection{Pharsalus}

\subsubsection{Environmental Factors}

After his speech at Dyrrachium, Caesar led his army across the Thessalian plain hoping to engage Pompey in the open field. Pompey, who had just won at Dyrrachium and had a much larger army (about 45,000 to Caesar's 22,000 at this point according to Caesar, who had received reinforcements from his commander Gnaeus Domitius Calvinus [13]), held higher ground and hoped for a defensive advantage. However, pressure from Pompey's associates to hurry up and finish the war led him to move out and engage Caesar's army. Caesar describes it thus:

After . . the signal for departure had already been given and the tents struck, it was noticed that a little earlier Pompey's battle line, exceeding what it had been used to doing each day, had moved forward farther from their rampart, so that it appeared possible to fight on ground that would not be unfavorable. Then Caesar, who was with his men as they were about to march out of the gate in formation, said to them, "We need to put off our march for now and turn our thoughts to battle, which is what we have been demanding all this time. 
Let's take courage and be prepared to fight. It will not be easy to find another chance later."

Then he immediately led out his troops, unencumbered and ready to fight [13].

Even Hansen the skeptic reckoned this speech may have actually happened, but argued that because it was so short it did not count as a true battlefield speech [6]. The exact site of the battle was unknown for nearly 2000 years, with many historians supposing that it happened south of the Epineus River, until F. L. Lucas suggested in 1921 that the battle be located on the north bank [43], which is now broadly accepted [44]. Because Pompey had come down out of the rougher hills to the west, it seems reasonable to model this as flat terrain as well.

However, unlike the controlled environment after Dyrrachium, the acoustic context of this speech is quite different. While in a gathering for the conveyance of information, we can assume Caesar's troops to be relatively quiet, in this instance, he specifically mentions that they were assembled and marching out the gate to challenge and exhaust Pompey. By Caesar's own account his troops were in battle formation and moving while he spoke to them, which would drastically increase the background noise. While we do not know the exact SPL this would produce, an optimistic figure is $55 \mathrm{~dB}_{\mathrm{A}}$, although the value could certainly be much greater.

\subsubsection{Simulation}

Caesar was simulated giving a speech to another $200 \mathrm{~m} \times 200 \mathrm{~m}$ grid, with the same environmental factors as at Dyrrachium above. His vocal level was modeled as $80 \mathrm{~dB}$ (the quieter value of $74 \mathrm{~dB}$ being discarded for now to explore only the most optimistic scenario). The background noise was modeled as $55 \mathrm{~dB}_{\mathrm{A}}$ to account for the louder noise of an army on the march. In addition, since Caesar's army was in formation, the greatest density that can be assumed for them is lower than at Dyrrachium, about 1 person per $\mathrm{m}^{2}$ [45]. Thus, Caesar's army was modeled using measured absorption values for a standing crowd with density of 1.17 persons per $\mathrm{m}^{2}$, as measured in [46] and shown in Table 3.

Table 3. Absorption coefficients by octave band center frequency (Hz) for soldiers in Pharsalus model (1.17 persons per $\left.\mathrm{m}^{2},[46]\right)$.

\begin{tabular}{ccccccc}
\hline Surface & $\mathbf{1 2 5}$ & $\mathbf{2 5 0}$ & $\mathbf{5 0 0}$ & $\mathbf{1 0 0 0}$ & $\mathbf{2 0 0 0}$ & $\mathbf{4 0 0 0}$ \\
\hline Audience area (dense) & 0.20 & 0.35 & 0.70 & 0.99 & 0.99 & 0.99 \\
\hline
\end{tabular}

Again, the STI map from CATT was exported and all intelligible grid squares' areas were summed in Matlab, with the difference this time that no space was allowed behind Caesar since he was presumably in front of his army when he addressed them (in general, cutting off the space behind a speaker, given the shape of the human voice's directivity pattern, will reduce the MIA for that scenario by about $20 \%$ ). The simulated MIA under these conditions is shown in Figure 2.

It can be seen that the predicted MIA drops drastically under these conditions, to $596 \mathrm{~m}^{2}$, as shown in Table 4. Thus, the greatest number of men that could have heard Caesar intelligibly at once is closer to 500 (the size of a single cohort) rather than his entire army of 22,000.

Table 4. Modeled crowd size, area, and density by vocal source level.

\begin{tabular}{ccccc}
\hline Vocal SPL $\left(\mathbf{d B}_{\mathbf{A}}\right)$ & Background Noise Level $\left(\mathbf{d B}_{\mathbf{A}}\right)$ & MIA $\left(\mathbf{m}^{2}\right)$ & Density $($ Persons/m & \\
& & Crowd Size \\
\hline 80 & 55 & 596 & 1.17 & 697 \\
\hline
\end{tabular}




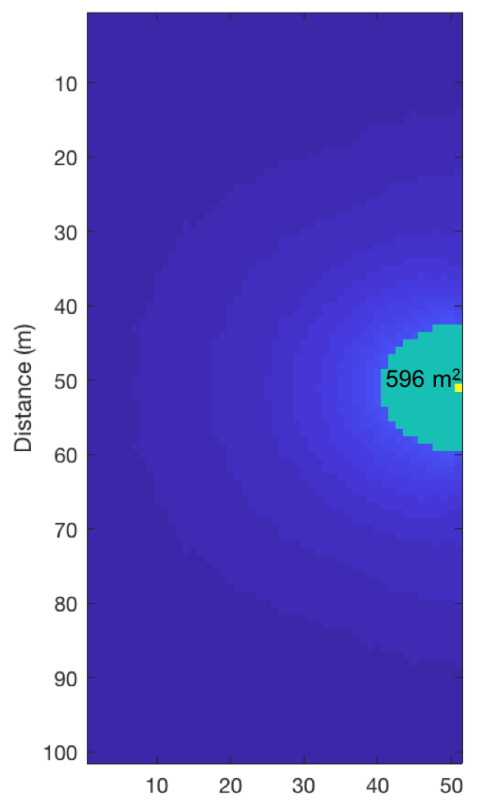

Figure 2. Minimally Intelligible Area (MIA) at Pharsalus.

\section{Discussion}

Based on these simulations, we may shed new light on the acoustical plausibility of these two speeches, which will affect our interpretation of Caesar's account. At Dyrrachium, we simulated rather pessimistic conditions-giving Caesar only a $6 \mathrm{~dB}$ boost above normal loud speech, while assuming background noise of $45 \mathrm{~dB}_{\mathrm{A}}$, over $10 \mathrm{~dB}$ greater than that measured at some ancient Greek amphitheaters [47]. It can be seen from the simulations that, even under these relatively pessimistic conditions, Caesar could have plausibly spoken to all his 14,000 soldiers at once (leaving room for more!), as long as he did not speak with a "normal" vocal level of $74 \mathrm{~dB}$. Since the pessimistic case is plausible, we do not need to stretch the bounds of the simulation by probing how loud Caesar might have been, how quiet his men might have been, or assuming the existence of atypical environmental propagation, such as refraction patterns via a temperature inversion that would have carried his voice farther. The historical details must be sorted out by historians, but acoustically it must be said that this speech seems physically valid based on the descriptions we have of the event.

In contrast, before Pharsalus, even assuming the louder value for Caesar and a relatively quiet noise value for his army, his MIA value decreases by an order of magnitude. The maximum width of his intelligible area is less than $20 \mathrm{~m}$, while the battlefront stretched up to $3 \mathrm{~km}$ once the armies were engaged [44]. Even assuming his army was somewhat more compact before he spoke to them, there does not appear to be any acoustically plausible scenario in which he could be heard intelligibly by his entire force if they were all in front of him, arranged less densely, and on the move. Since the optimistic case does not appear plausible, there is no need to simulate greater background noise values. In both cases, there is clearly some uncertainty about Caesar's exact STI value, vocal level, and background noise. However, by considering an implausible optimistic scenario or a plausible pessimistic scenario, it is possible to speak confidently about the general plausibility of an account even if we cannot know the precise intelligibility value at each point in the crowd.

Having made this acoustical point, however, it should not be inferred that Caesar's speech as written did not happen - it is quite possible that he did speak something similar to the soldiers and officers nearby when he realized Pompey's forces were extended far enough to engage them. The signal to engage could then have been conveyed by messengers, trumpet signal, or flag signals, all of which 
Caesar used during the Civil War [13]. In fact, as Pompey's cavalry attempted to flank his right side, Caesar reacted as follows:

However, once [Caesar] had a look at the enemy formation described above, he feared a flanking attack by the mass of enemy cavalry circling around his right wing; he therefore rapidly drew individual cohorts out of the third line of his formation, placed them as a fourth line to oppose Pompey's cavalry, and explained to them what he wanted them to do, making it clear that this day's victory would depend on the bravery of these cohorts. At the same time he commanded the third line not to move forward and engage with the enemy without explicit orders from himself: when he wanted this to happen, he would give the signal with a flag [13].

This action seems to be largely improvised, as Caesar recorded himself explaining and commanding his soldiers verbally of what they were about to do. Assuming that he could make himself heard by a single cohort of 500 men in formation, this seems reasonably in line with him riding behind his third line and speaking multiple times to multiple cohorts as he formed them into the fourth line which would counterattack Pompey's cavalry, resulting in Caesar's successful flank of Pompey, the route of Pompey's forces, and the end of the Civil War. The fact that Caesar ordered them all to coordinate this action by a flag signal again shows that he did not expect to be able to verbally communicate with his entire army, or even a portion of it, during the battle itself. However, his reported oratorical skill would have come in useful in this and many other noisy battles where Caesar's instincts and improvisational abilities led his forces to many such incredible victories and very few defeats.

Although this discussion has focused mainly on Caesar, clearly many such pitched battles between ancient armies occurred on fairly flat terrain without many significant reflecting surfaces, so these simulations may be seen as a proxy for any male speaker with the level and background noise conditions assumed here. This may be less useful for modern assemblies, which generally have electrical amplification, but it can be viewed as a lens through which to consider other ancient reported speeches before armies. However, for each situation, the orator's vocal ability, training, and age should be considered, along with the likely background noise of the crowd listening.

\section{Conclusions}

The simulations above show that Caesar's post-battle speech at Dyrrachium seems acoustically plausible, even without assuming optimistic conditions. In contrast, Caesar's speech before the battle at Pharsalus cannot plausibly have been heard intelligibly by most of his army in formation and on the march. This does not necessarily imply that we should adopt the extreme skepticism of Hansen, who doubted that commanders could even address 1000 soldiers at once in formation [6]. In other cases, when forces were drawn up to a static position before a battle, it may have been acoustically possible for their commanders to address all of them at once, depending on vocal level and background noise. Other cases such as accounts from Thucydides or Henry V's speech before Agincourt, seem to fall into this category, and require separate simulations to account for the particulars of each account. However, Caesar's speech at Pharsalus should be considered a local order to the troops immediately around him, rather than a grand address given to the entire army.

Funding: This research received no external funding.

Conflicts of Interest: The author declares no conflict of interest.

\section{References}

1. Thucydides. History of the Peloponnesian War; Bohn: London, UK, 1843.

2. Jacobs, H.A. To count a crowd. Columbia Journal. Rev. 1967, 5, 37-40.

3. Seidler, J.; Meyer, K.; Gillivray, L.M. Collecting Data on Crowds and Rallies: A New Method of Stationary Sampling. Soc. Forces 1976, 55, 507-519. [CrossRef] 
4. Murphy, C.T. The Use of Speeches in Caesar's Gallic War. Class. J. 1949, 45, 120-127.

5. Miller, N.P. Dramatic Speech in the Roman Historians. Greece Rome 1975, 22, 45-57. [CrossRef]

6. Hansen, M.H. The battle exhortation in ancient historiography: Fact or fiction? Historia 1993, 42, 161-180.

7. Pritchett, W.K. The General's Exhorations in Greek Warfare. In Essays in Greek History; J. C. Gieben: Amsterdam, The Netherlands, 1994; pp. 27-109.

8. Rufus, Q.C. History of Alexander; Harvard University Press: Cambridge, MA, USA, 1946.

9. Wesley, J. The Journal of John Wesley; Moody Press: Chicago, IL, USA, 1951.

10. Watson, R.; Yip, P. How many were there when it mattered? Significance 2011, 8, 104-107. [CrossRef]

11. O'Neill, T. The Great Myths 5: The Destruction of The Great Library of Alexandria. 2017. Available online: https:/ / historyforatheists.com/2017/07/the-destruction-of-the-great-library-of-alexandria/ (accessed on 8 February 2018).

12. Bordes, N.; Pailthorpe, B.; Hall, J.; Loy, T.; Williams, M.; Ulm, S.; Zhou, X.; Fletcher, R. Computational Archaeology. In Proceedings of the WACE 2004: Workshop on Advanced Collaborative Environments, Nice, France, 23 September 2004.

13. Raaflaub, K.A. (Ed.) The Landmark Julius Caesar; Pantheon Books: New York, NY, USA, 2017.

14. Ehrhardt, C.T.H.R. Speeches before Battle? Hist. Z. Alte Gesch. 1995, 44, 120-121.

15. Nordling, J.G. Caesar's Pre-Battle Speech at Pharsalus (B.C. 3.85.4): Ridiculum Acri Fortius ‥ Secat Res. Class. J. 2005, 101, 183-189.

16. Zoido, J.C.I. The Battle Exhortation in Ancient Rhetoric. Rhetorica 2007, 25, 141-158. [CrossRef]

17. Dallimore, A. George Whitefield: The Life and Times of the Great Evangelist of the Eighteenth-Century Revival; Banner of Truth Trust: London, UK, 1970.

18. Franklin, B. The Autobiography of Benjamin Franklin, 2nd ed.; Yale University Press: New Haven, CT, USA; London, UK, 1964.

19. Stout, H. The Divine Dramatist: George Whitefield and the Rise of Modern Evangelicalism; William B. Eerdmans Publishing Company: Grand Rapids, MI, USA, 1991.

20. Boren, B.B.; Roginska, A. Analysis of noise sources in colonial Philadelphia. Internoise 2012, 9, 7543-7553.

21. Boren, B.B.; Roginska, A. Maximum Averaged and Peak Levels of Vocal Sound Pressure. In Proceedings of the 135th Audio Engineering Society Convention, New York, NY, USA, 17-20 October 2013.

22. Boren, B.B.; Roginska, A. Sound Radiation of Trained Vocalizers. In Proceedings of the Meetings on Acoustics: 21st International Congress on Acoustics, New York, NY, USA, 4 May 2013.

23. Boren, B.B. George Whitefield's Voice. In George Whitefield: Life, Context and Legacy; Jones, D.C., Hammond, G., Eds.; Oxford University Press: Oxford, UK, 2015.

24. American National Standards Institute. American National Standard: Methods for Calculation of the Speech Intelligibility Index; Acoustical Society of America: New York, NY, USA, 1997.

25. Rindel, J.H. Odeon Application Note-Calculation of Speech Transmission Index in Rooms; Odeon A/S: Lyngby, Denmark, 2014.

26. International Organization for Standardization. ISO 9921: 2003 Ergonomics-Assesment of Speech Communication; International Organization for Standardization: Geneva, Switzerland, 2003.

27. Forrest, T.G.; Raspet, R. Models of female choice in acoustic communication. Behav. Ecol. 1994, 5, $293-303$. [CrossRef]

28. Mendes, A.P.; Rothman, H.B.; Sapienza, C.; Brown, W. Effects of vocal training on the acoustic parameters of the singing voice. J. Voice 2003, 17, 529-543. [CrossRef]

29. Kahn, A. The Education of Julius Caesar; Schocken Books: New York, NY, USA, 1986.

30. Plutarch. The Parallel Lives; Loeb Classical Library: Cambridge, MA, USA; London, UK, 1919.

31. Sallust. Conspiracy of Catiline; Harper and Brothers: New York, NY, USA; London, UK, 1899.

32. Cicero, M.T. De Oratore; Harvard University Press: Cambridge, MA, USA, 1967.

33. Suetonius, G. The Twelve Caesars; Penguin Books: London, UK, 1957.

34. Dobson, J.F. The Greek Orators; Methuen and Co.: London, UK, 1919.

35. Kent, R.; Kent, J.; Rosenbek, J. Maximum Performance Tests of Speech Production. J. Speech Hear. Disord. 1987, 52, 367-387. [CrossRef] [PubMed]

36. Dalenbäck, B.I.L. Room Acoustic Prediction Based on a Unified Treatment of Diffuse and Specular Reflection. J. Acoust. Soc. Am. 1996, 100, 899-909. [CrossRef]

37. Dalenback, B. CATT-Acoustic v9; CATT: Gothenburg, Sweden, 2011. 
38. Rindel, J. The Use of Computer Modeling in Room Acoustics. J. Vibroeng. 2000, 3, $219-224$.

39. Siltanen, S.; Lokki, T.; Savioja, L. Rays or Waves? Understanding the Strengths and Weaknesses of Computational Room Acoustics Modeling Techniques. In Proceedings of the International Symposium on Room Acoustics, Melbourne, Australia, 29-31 August 2010.

40. Forrest, T.G. From Sender to Receiver: Propagation and Environmental Effects on Acoustic Signals. Am. Zool. 1994, 34, 644-654. [CrossRef]

41. Adelman-Larsen, N.W.; Thompson, E.R.; Gade, A.C. Suitable reverberation times for halls for rock and pop music. J. Acoust. Soc. Am. 2010, 127, 247-255. [CrossRef] [PubMed]

42. Steeneken, H.J.M.; Houtgast, T. Basics of the STI measuring method. In Past, Present and Future of the Speech Transmission Index; van Wijngaarden, S.J., Ed.; TNO Human Factors: Soesterberg, The Netherlands, 2002; pp. 13-43.

43. Lucas, F.L. The Battlefield of Pharsalos. Annu. Br. Sch. Athens Suppl. 1921, 24, 34-53. [CrossRef]

44. Morgan, J.D. Palaepharsalus-The Battle and the Town. Am. J. Archaeol. 1983, 87, 23-54. [CrossRef]

45. James, S. 48 BC: The Battle of Pharsalus. In Rome's Legions: Decoding Their Pythagorean Organization 753 BC to 410 AD; Academia: Prague, Czechoslovakia, 2010.

46. Martellotta, F.; D'Alba, M.; Crociata, S.D. Laboratory measurement of sound absorption of occupied pews and standing audiences. Appl. Acoust. 2011, 72, 341-349. [CrossRef]

47. Bo, E.; Kostara-Konstantinou, E.; Lepore, F.; Shtrepi, L.; Puglisi, G.; Astolfi, A.; Barkas, N.; Mangano, B.; Mangano, F. Acoustic characterization of the ancient theatre of Tyndaris: Evaluation and proposals for its reuse. In Proceedings of the ICSV 2016-23rd International Congress on Sound and Vibration: From Ancient to Modern Acoustics, Atene, Greece, 10-14 July 2016.

(C) 2018 by the authors. Licensee MDPI, Basel, Switzerland. This article is an open access article distributed under the terms and conditions of the Creative Commons Attribution (CC BY) license (http:/ / creativecommons.org/licenses/by/4.0/). 